\title{
Ominous Phenomena such as Fraud and Forgery
}

\author{
Hamid Reza Mirza Jani ${ }^{1} \&$ Fatemeh Mirdad ${ }^{1}$ \\ ${ }^{1}$ Department of Law, Islamic Azad University, Mashhad, Iran \\ Correspondence: Hamid Reza Mirza Jani, Department of Law, Islamic Azad University, Mashhad, Iran. E-mail: \\ drmirzajani@yahoo.com
}

Received: March 1, 2017

Accepted: March 30, 2017 Online Published: June 23, 2017

doi:10.5539/ass.v13n7p10

URL: https://doi.org/10.5539/ass.v13n7p10

\begin{abstract}
The main aim of this investigation is to examine crimes such as fraud and forgery and characteristics of convicts in a new context. To this end, prisoners are grouped in terms of their statuses in Mashhad city and some characteristics of convicts including sex ratio, marital status, educational level, and occupational status are studied. Using data analysis, proportions of the data are analyzed and the findings show that characteristic of convicts are important factors in committing crimes. That is, characteristics of convicts have influence on their fraud and forgery crimes. As well, crime management is another major issue in this research. Crime management can be not only controlling and limiting the convicts, but also informing the victims. Victims should be kept better informed of the consequences of cupidity or credulity. Therefore, the issue of characteristics of convicts is an intriguing one which can help us find strengthen and weakness of current solutions and problems.
\end{abstract}

Keywords: fraud, forgery, characteristics of convicts

\section{Introduction}

Crimes such fraud and forgery can take different forms and paly parts in the debilitation of a society. Fraud and forgery not only disappoint the citizens but also endanger the economy and culture. When culture and economy as main parts of a country is debilitated, the body of that country will be sensitive and vulnerable. In law, forgery means using a false writing or handwriting in order to deceive and gain some personal advantages. Some documents such as contracts, deeds, and checks are at the risk of forgery. On the other hand, the fraud is a deliberate attempt to give a false account and to misrepresent the facts with the intent to exclude a person or some persons from real rights. As well, any covering or concealment that is harmful to individuals or that permits an individual to misuse people is called fraud. There are some types of fraud, for example, giving a check without enough money in the signer's account, using a false identity, or sending fictitious mails. (Merriam-Webster, 2015). The other side of the coin is crime management. Crime management means paying serious attentions to victims, convicts and their social statuses. That is, victims should be well-informed of the side-effects of crimes in order to decrease crimes such as fraud and forgery in the society. In fact, socio-economic status of convicts should be studied to find solutions for these ominous phenomena. Crime management means blocking crime ways, authorizing organizations and foundations, and empower the law in terms of administration (I.R. Police, 2015). According to ISNA, "to avoid fraud and forgery, people should made their contracts in official offices and enter into contracts under supervision of law. Individuals should take care of their certificates, documents and ID cards carefully and should not hand in unknown persons. In general, getting rich overnight is dubious and citizens should not tempt fate" (Quds online, 2015). Due to cultural and religious context, sex ratio and marital status play important roles in Iran. Although traditional beliefs are strong among Iranians, new generation commits such crimes because of sanction and economic stagnation. When economic factor is not strong, educational and occupational factors cannot control crime rates exactly. Consequently, poverty comes again, and again there will be fraud and forgery. Therefore, the issue of characteristics of convicts is really important and now the time had come for Iranian policy makers to pay serious attention to these characteristics to reduce crime rates.

\section{Review of Literature}

This section examines the legal element of the crime of fraud in Iran. Legal element as a main base of physical and mental element is a part of the legality of crime and punishment. Due to the legal element of a crime, a special behavior or mood is known as mental and physical element (Sharahi, 2008). Under Iran's legal system, 
Provisions (Article 300) related to the fraud crime were derived from French Penal Code and issued in 1282. This issue was changed under Article 238 in 1926. Due to some ambiguous points, those provisions were modified as a single Article in order to prevent dual interpretations in 1936. In 1977, although the Article 238 did not change, its statements and words changed completely. After the Iranian Revolution (the Islamic Revolution), Public Penal Code had changed to Islamic Penal Code under General Act 116 in 1984. Finally, it was approved in 1989 including Article 1 named fraud crime (Salari, 2008). According to Iranian criminal law, forgery (Article 523) means making of a false handwriting, document, seal or signature, scratching or printing, engraving, changing the date of deed (documents) or adding something to it without permission( and with the intention). On the other hand, fraud (Article 1) is deceiving people to establish companies, factories, or institutes, and to have false properties and authorities, or raising their hopes in order to have unreal things, dreading them, abetting people to obtain money, drafts, deeds, documents, negotiable instruments (Zahedi,2013). Mirmohamad Sadeghi (2012) believes that forgery is the process of using tools or making fraudulent acts with bad intention to deceive individuals to earn money or important documents and forgery is the action of creating an exact replica of a produced or altered object such as a document, statistics, or money with sinister intention of deceiving or the misuse of objects. And Habibzadeh (2013) indicates that making a false instrument base to accompany by inducing victims. Depriving people of a valuable possession as a deliberate misrepresentation endanger the society and its security. When economic security of a country is endangered, financial crimes will destroy the whole family system. In order to prevent these ominous phenomena, crime management can be a deterrent factor.

Therefore, the aim of this study is to examine crimes such as fraud and forgery and characteristics of convicts in a new context.

The hypothesis that will be tested is that:

1. To what extent do crimes such as fraud and forgery is affected by characteristics of prisoners?

\section{Method}

The main aim of this investigation is to examine the relationship between prisoners, their characteristics and crimes in a new context called Mashahd, Iran. The participants were guilty of fraud and forgery in 2013. To do this, we analyzed social characteristics of convicts.

\subsection{Participants}

The number of convicts are 4000 and range in age from 18 to 60 , but $16 \%$ were young adults, $40 \%$ were mature adults, $38 \%$ were old adults, and the rest $6 \%$ were under 22 . In fact, the population of males and females (sex ratio) are the same nearly.

\subsection{Instruments}

We investigated the personal and social characteristics of convicts based on available documents. Therefore, the tables show to what extent the variables have influence on crimes.

\subsection{Procedure}

To do the present research, we used some documents related to the characteristics of convicts and thir crimes from Mashhad Prison.

\subsection{Data Analysis}

After categorizing the attributes and characteristics of 4000 convicts, we used a few statistical analyses in order to show the probable relationship the attributes of prisoners and their committed crimes. The following tables consist of some variables displaying their occupational and educational level, sex, and statuses.

\section{Discussion}

In order to find possible solutions for crime prevention, the investigation of characteristics of convicts can help us control crimes and limit convicts. When occupational and educational levels of individuals develop, there will be no room for crimes such as fraud and forgery. Poverty is a powerful factor to disappoint people and to commit crimes. It may instigate individuals to get rich overnight. In fact, economic factor overcomes religious belief. So, society needs help. Education and occupation are the axes of development. Therefore, policy makers are not only deterrent powers, they are responsible for providing social justice. They can pave the way for not only all citizens but also all injured people. Convicts are parts of the society that can be revitalized. Although convicts do not deserve a pat on the back, they also do not deserve inattention.

The present study investigates the probable relationship between characteristics of convicts and their fraud and 
forgery crimes.

The following tables show social statues of convicts and their crimes in Mashhad Prison. Mashhad is a main and important city in Iran. Table 1 shows population density in terms of region, number, and sex.

Table 1. Population density in Mashhad

\begin{tabular}{cllll}
\hline Region & No & Male & Female & Sex Ratio \\
\hline 1 & 176104 & 85714 & 90390 & 94.8 \\
2 & 485833 & 242648 & 243185 & 99.8 \\
3 & 322018 & 161265 & 160753 & 100.3 \\
4 & 244944 & 122566 & 122378 & 100.2 \\
5 & 168876 & 84461 & 84415 & 100.1 \\
6 & 253963 & 126940 & 127023 & 99.9 \\
7 & 206968 & 104618 & 102350 & 102.2 \\
8 & 94040 & 46505 & 47535 & 97.8 \\
9 & 300246 & 147934 & 152312 & 97.1 \\
10 & 264523 & 132522 & 132001 & 100.4 \\
11 & 192223 & 100543 & 91680 & 109.7 \\
12 & 39636 & 20169 & 19467 & 103.6 \\
13 & 16884 & 8714 & 8170 & 106.7 \\
Total & 2766258 & 1384599 & 1381659 & 100.2 \\
\hline
\end{tabular}

The number of Mashhad citizens were 2766258 in 2013 (Center of Statistical Management and Data analysis, 2015). Mashhad as a religious city is located in the northeast of the country and its activities are also important to Iranian Government. As can be seen in the table, $50.1 \%$ of the citizens are male and $49.9 \%$ are female. The table shows that the population of males and females (sex ratio) are the same nearly.

Table 2. Number of Convicts

\begin{tabular}{lll}
\hline Case & Fraud & Forgery \\
\hline Number & 2200 & 1800 \\
\hline
\end{tabular}

Table 2 shows the number of prisoners who were sentenced for crimes such as fraud and forgery in 2013 . Totally, the number of convicts are 4000 . Prisoners are from 18 years old to 60 years old, but $16 \%$ were young adults, $40 \%$ were mature adults, $38 \%$ were old adults, and the rest $6 \%$ were under 22 . We can see that the fraud $(0.08 \%)$ and forgery $(0.06 \%)$ rates are too low in comparison with population of Mashhad city. The proportion of fraud crime was higher than that of forgery crime.

Table 3. Sex Ratio

\begin{tabular}{|c|c|c|c|c|}
\hline \multirow[t]{2}{*}{ Sex } & \multicolumn{2}{|l|}{ Male } & \multicolumn{2}{|c|}{ Female } \\
\hline & Fraud & Forgery & Fraud & Forgery \\
\hline \multicolumn{5}{|l|}{ Age } \\
\hline $18-22$ & 322 & 280 & 30 & 8 \\
\hline 23-35 (young adults) & 800 & 700 & 80 & 20 \\
\hline 35-45 (mature adults) & 800 & 660 & 36 & 24 \\
\hline 46-60 (old adults) & 128 & 105 & 3 & 4 \\
\hline
\end{tabular}




\begin{tabular}{llllr}
\hline Total & 2050 & 1745 & 149 & 56
\end{tabular}

The Table 3 indicates that $16 \%$ of crimes were committed under age $22.40 \%$ were young adults and $38 \%$ were mature adults. Another $6 \%$ were old adults. We can see from the table that women rarely committed crimes such as fraud and forgery. In fact, young and mature adults were guilty of fraud and forgery. It is apparent from this table that males were much higher proportion of those sentenced for fraud and forgery.

Table 4. Marital Status

\begin{tabular}{lllll}
\hline & Male & & Female & \\
\cline { 2 - 5 } & Fraud & Forgery & Fraud & Forgery \\
\hline Married & 783 & 708 & 19 & 16 \\
Single & 433 & 379 & 40 & 10 \\
Divorced & 834 & 658 & 90 & 30 \\
\hline
\end{tabular}

Table 4 shows that the majority of male convicts were married (40\%) and divorced (40\%). On the other hand, the majority of female convicts were single $(40 \%)$ and divorced $(40 \%)$. Not many single prisoners (male) and married prisoners (female) participated in crimes. These results suggest that divorce case is a strong factor for committing crimes.

Table 5. Educational Level

\begin{tabular}{lllll}
\hline & Male & & Female & \\
\cline { 2 - 5 } & Fraud & forgery & Fraud & Forgery \\
\hline - Diploma & 650 & 671 & 35 & 6 \\
Diploma - Bachelor of Arts (BA) & 790 & 703 & 95 & 20 \\
+ BA & 610 & 371 & 19 & 30 \\
\hline
\end{tabular}

We can see from table 5 that the male convicts are partly distributed across the educational level. That is, $40 \%$ of male convicts have Diploma/ BA, 25\% have + BA, and the rest (35\%) have - Diploma. But more than half of female convicts $(65 \%)$ have Diploma/BA.

Table 6. Occupational Status

\begin{tabular}{lllll}
\hline & \multicolumn{2}{l}{ Male } & & Female \\
\cline { 2 - 5 } & Fraud & Forgery & Fraud & forgery \\
\hline Unemployment & 210 & 130 & 15 & 4 \\
Self-employment & 1790 & 1150 & 36 & 18 \\
Clerk & 59 & 61 & 98 & 34 \\
\hline
\end{tabular}

The table 6 indicates that the majority of male convicts were self-employed and the minority of male prisoners were clerk. On the other hand, $65 \%$ of female prisoners were clerks and $5 \%$ were unemployed. In the case of males, self-employment was an important factor and self-employed individuals committed those crimes more. But in the case of females, clerks were guilty of fraud and forgery. In short, although unemployment is not an important factor for females for committing crimes, unemployment and self-employment are important factors for males for committing crimes.

\section{Conclusion}

In English law "forgery is characterized as the making of a false report as if it is origin in order to defraud individuals. Forgery restricted to a document. Documents includes letters, wills, banknotes, pictures, paintings 
and many others" (Ramazani, 2009). According to Wikipedia (2015), forgers misuse documents or make statistics in order to take unconscionable advantage of people and their rights. In fact, they make the forged items, use or sell them to gain profit. Although willful and deliberate misrepresentations of copies are considered forgeries, using replicas is not forgery.

In general, a forgery is the process of altering or producing objects or documents. Also, fraud means obtaining the property and requires two components. The first component is making damages to the convict and the other one is making advantages of fraudulent property. These two components are really urgent (Mohammad Nezhad, 2011). Each fraud involves two main elements of concealment and theft act. On the one hand, concealment consists of taking some steps by the perpetrators to hide and selling or converting stolen assets into cash. On the other hand, theft act consists of taking information, document, and money manually or by computer (Wikipedia, 2015).

In summary, the results of this study show that characteristics of prisoners can have influence on their crimes. That is, young and adult convicts are much higher proportion of those sentenced for fraud and forgery crimes and divorce case is a strong factor for committing crimes. As well, the male convicts are partly distributed across the educational level and more than half of female convicts have Diploma/BA. In the case of males, self-employed individuals committed those crimes more. But in the case of females, clerks were guilty of fraud and forgery. It seems that crime management as a powerful instrument can decrease or prevent the crime rates in Iran. Situational prevention lies in the body of crime management. It involves to create a situation that is difficult to commit crime. Crime management decreases the potential of committing crimes and disappoint forgers. (Clark, 1997). And crime control as a deterrent phenomenon paves the way for security. It consists of interlocking strategies, techniques and structures of old and new elements. In order to control crimes, it is necessary to pay attention to the nature of crimes and characteristics of convicts. The nature of crime control is characterized and revitalized by new attitudes towards convicts (Owen, 2007). In order to reduce and control crimes, new policies are required in terms of regulations. Because social justice and public safety should be on the list of priorities of government. One of the advantages of crime control is public order. The other one is law enforcement. To this end, social and criminal justice agencies should use new management styles and decrease the criminal acts taking advantage of new strategies. Therefore, system management is an urgent need. According to Hall, it consists of specialization in all elements of a system. It also needs a strong communications among subsystems.

To sum up, we can draw a conclusion that personal and social characteristics of convicts and their committed crimes are strong factors. To rebuild a society or to revitalize the injured individuals, social and economic variables play important roles. Education paves the way for welfare and welfare paves the way for crime prevention. They need mutual supports. If we want to manage the crime rates, it is vital to improve educational and occupational levels in the society (Sajedi \& Shaygan Fard, 2015). It could be said that characteristics of convicts have influence on their fraud and forgery crimes. As well, crime management is another major issue in this research. Crime management can be not only controlling and limiting the convicts, but also informing the victims. Victims should be kept better informed of the consequences of cupidity or credulity. Therefore, the issue of characteristics of convicts is an intriguing one which can help us find strengthen and weakness of current solutions and problems.

\section{References}

Center of Statistical Management and Data Analysis. (2015). Retrieved from http://amar.mashhad.ir.

Clark, R. V. (1997). Situational crime prevention: Successful case studies. Guilderland, New York: Harrow and Heston Publications.

Gudsonline Newspaper. (2015). Retrieved from http://qudsonline.ir/detail/News/251435

Habibzadeh, M. J. (2013). Frauad in Iran law. Tehran: Shahid University Publications.

Hall, Sh, (2015). What are crime control policies? Retrived from http://www.ehow.com/facts-5824748-crime-control-policies-.html

I.R. Police (2015). Retrieved from http://www.news.police.ir/News/

Merriam-Webster Dictionary. (2015). Retrieved from http://www.merriam-webster.com

Mirmohamad Sadeghi, H. (2012). Crimes against property. Tehran: Mizan Publications

Mohammad Nezhad, P. (2011). Nurture Magazine. Tehran: Developmental Center of Research and training Services Publications. 
Owen, T. (2007). Culture of crime control: Through a post-Foucauldian lens. Internet Journal of Criminology. www.internetjournalofcriminology.com

Ramazani, M. (2009). Law text. Tehran: Nasle Nikan Publications

Sajedi, F., \& Shaygan Fard, M. (2015). Stealing and holding stolen goods. Asian Social Science, 11(22). https://doi.org/10.5539/ass.v11n22p133

Salari, (2008). Fraud. Tehran: Mizan Publications

Sharahi, A. (2008). Fraud in current legal order. Tehran: Asahre Andisheh Publications

Statistical Management and Data Analysis. (2015). Retrieved from http://amar.mashhad.ir.

Wikipedia. (20015). Retrieved from http://en.wikipedia.org

Zahedi, A. (2013). Collection of law. Tehran. Iran: Jungle Publication

\section{Copyrights}

Copyright for this article is retained by the author(s), with first publication rights granted to the journal.

This is an open-access article distributed under the terms and conditions of the Creative Commons Attribution license (http://creativecommons.org/licenses/by/4.0/). 